\title{
Sustainable Energy System of EI Hierro Island
}

\author{
R. Godina ${ }^{1}$, E. M. G. Rodrigues ${ }^{1}$, J. C. O. Matias ${ }^{1}$, J. P. S. Catalão ${ }^{1,2,3}$ \\ ${ }^{1}$ University of Beira Interior, R. Fonte do Lameiro, 6200-001, Covilhã, Portugal, \\ ${ }_{2}^{2}$ INESC-ID, R. Alves Redol, 1000-029, Lisbon, Portugal, \\ ${ }^{3}$ IST, University of Lisbon, Av. Rovisco Pais, 1049-001, Lisbon Portugal \\ Corresponding author email: catalao@ubi.pt
}

\begin{abstract}
Isolated islanded energy systems do not have any connection to continental grids and nor do have an easy access to conventional energy sources. In order to face this specific challenge, El Hierro project on the small El Hierro island, Canary Islands, was put in practice. This project embodies the first major Megawatt-level energy project by linking energy storage systems with wind power generation using water storage delivered by the pumping system between two artificial lakes. In this paper, we analyse the project and discuss the first results after the inauguration.
\end{abstract}

\section{Key words}

Sustainable energy system, El Hierro project, energy storage systems, isolated energy systems.

\section{Introduction}

A clear example of an isolated energy system is the El Hierro Island from The Canary archipelago - a group of islands of a relative important size within the EU. Fully isolated electricity grids such as these islands contain a set of features that commonly imply an increased energy dependence and vulnerability, thus, it demands a need for precise planning. These energy systems do not have an easy access to every existing energy source and the connection to continental grids is missing. Therefore high fuel transportation costs which result from remote supply sources and a lack of endogenous fossil energy sources translates in increased costs. Therefore, energy from renewable sources complemented with fossil fuels presents a firm path to achieve a feasible solution. A study of the recently implemented electricity production system in El Hierro Island can be seen as a model for other similar sized insulated systems in which the only endogenous energy is obtained from renewable sources. Isolated electrical systems suffer from several disadvantageous features such as the unpredictability of the electricity generation from renewable sources, high fuel transportation costs which result from remote supply sources and a lack of endogenous fossil energy sources which translates in increased costs. The smaller the size an electrical system the bigger expenses will be.
The production units mustn't surpass a certain size since a malfunctioning of a section could originate high percentage failure of the entire system. As a consequence, the electricity grid cannot be adequately exploited like it is in large continental systems, which results in an increased technical control complexity of frequency and voltage of the grid. To complicate this scenario the insularity imposes a larger reserve capacity to assure an adequate supply. Under these conditions, the introduction and development of energy production system from renewable sources complemented with fossil fuels seems the logic step to stop the increased high costs and at same time paving the way for advanced sustainable energy system development.

El Hierro is the smallest island of the Canaries and like the rest of the archipelago islands it relies significantly on diesel consumption - an external source of energy and features almost no diversification and it had a population of 10,995 inhabitants according to INE in 2011. The evolution and forecast of the population of the island of El Hierro between 2003 and 2020 can be seen in Fig. 1.

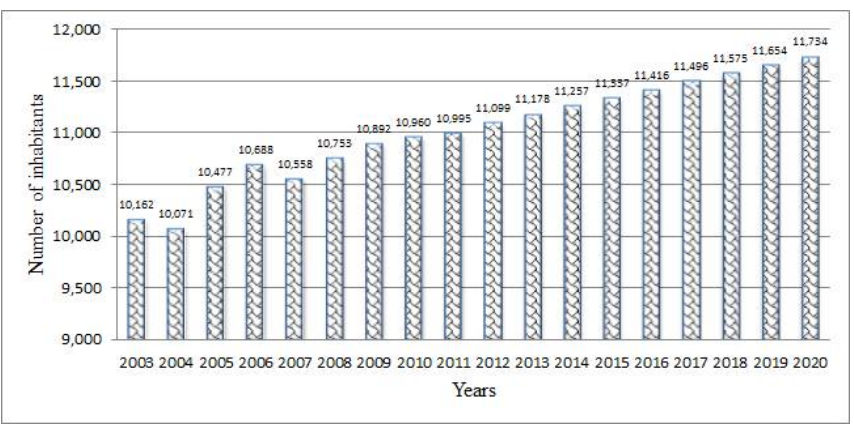

Figure 1 - Population evolution and forecast for the island of El Hierro.

The electricity generation costs are high on Canary Islands due to a fragmented energy production structure in different energy generating technologies. In average the most expensive primary energy is diesel while the wind energy has two times a lower cost [1]. El Hierro is a singular case among the rest of the islands. Being remotely located and using for their demand only diesel fuel, local energy system exploration is the most expensive per capita in the universe of the Canary Islands. 
And yet the island has plenty of natural resources such as wind and sun which could be explored. For increasing the penetration of Intermittent Energy Sources in insular systems towards an insular $100 \%$ sustainable energy system, an ambitious project was started in 2004 to convert the El Hierro in the world's first insular hybrid hydro-wind electricity generation system. Its commissioning is scheduled for 2015 [2].

The proposed hydro-wind power plant integrates a wind farm along with a pumped-storage hydroelectric power station. Wind power will supply directly the demand of the island of El Hierro in times of high wind energy production and indirectly during the rest of the time, through the discharge of water stored in an upper reservoir, which has previously been pumped from a lower reservoir when the produced wind energy was in surplus. The water storage delivered by the pumping system converts originally intermittent wind power generation into manageable energy, which is not only a better use of wind energy, but also offers better manageability and greater stability for the power system as a whole.

\section{Technical Characteristics}

Currently, the configuration of the Hydro-wind project of El Hierro's [3], Fig. 2, is made by the following elements:
- The Top Deposit: It is located at the "La Caldera" crater and it has a maximum capacity of $380,000 \mathrm{~m}^{3}$ and two drain intakes with PVC-sheet waterproofing and it is repairable underwater.

- The Bottom Deposit: It is located in same surrounding area as diesel power plant "Llanos Blancos" and it will have a useful capacity of $150,000 \mathrm{~m}^{3}$ made up of a dam built for this purpose with loose materials like PVC-sheet waterproofing and it will also be repairable under the water.

- Were also built forced conductions formed by two aerial pipes with a $530 \mathrm{~m}$ stretch under a thistle area in the gallery with $0,8 \mathrm{~m}$ diameter and $3015 \mathrm{~m}$ discharge conduction, with $1 \mathrm{~m}$ diameter and $2,350 \mathrm{~m}$ turbine capacity conduction and a $1 \mathrm{~m}$ and $188 \mathrm{~m}$ aspiration conduction.

- The Pumping Plant is installed in a newly-constructed building it is formed by two $1500 \mathrm{~kW}$ pump sets and 6 $500 \mathrm{~kW}$ pump sets with a total power of $6 \mathrm{MW}$ and it also has $1500 / 500 \mathrm{~kW}$ variators.

- The Turbine Capacity Plant is made by 4 Pelton groups of $2,830 \mathrm{~kW}$ of power each, for a total power of 11,32 MW and the maximum flow during generation is $2.0 \mathrm{~m}^{3} / \mathrm{s}$ with a gross head of 655 metres.

- The Wind Farm is constituted by a set of 5 aerogenerators (Enercon E-70) each with 2.3 MW of power which makes a total power of $11.5 \mathrm{MW}$.

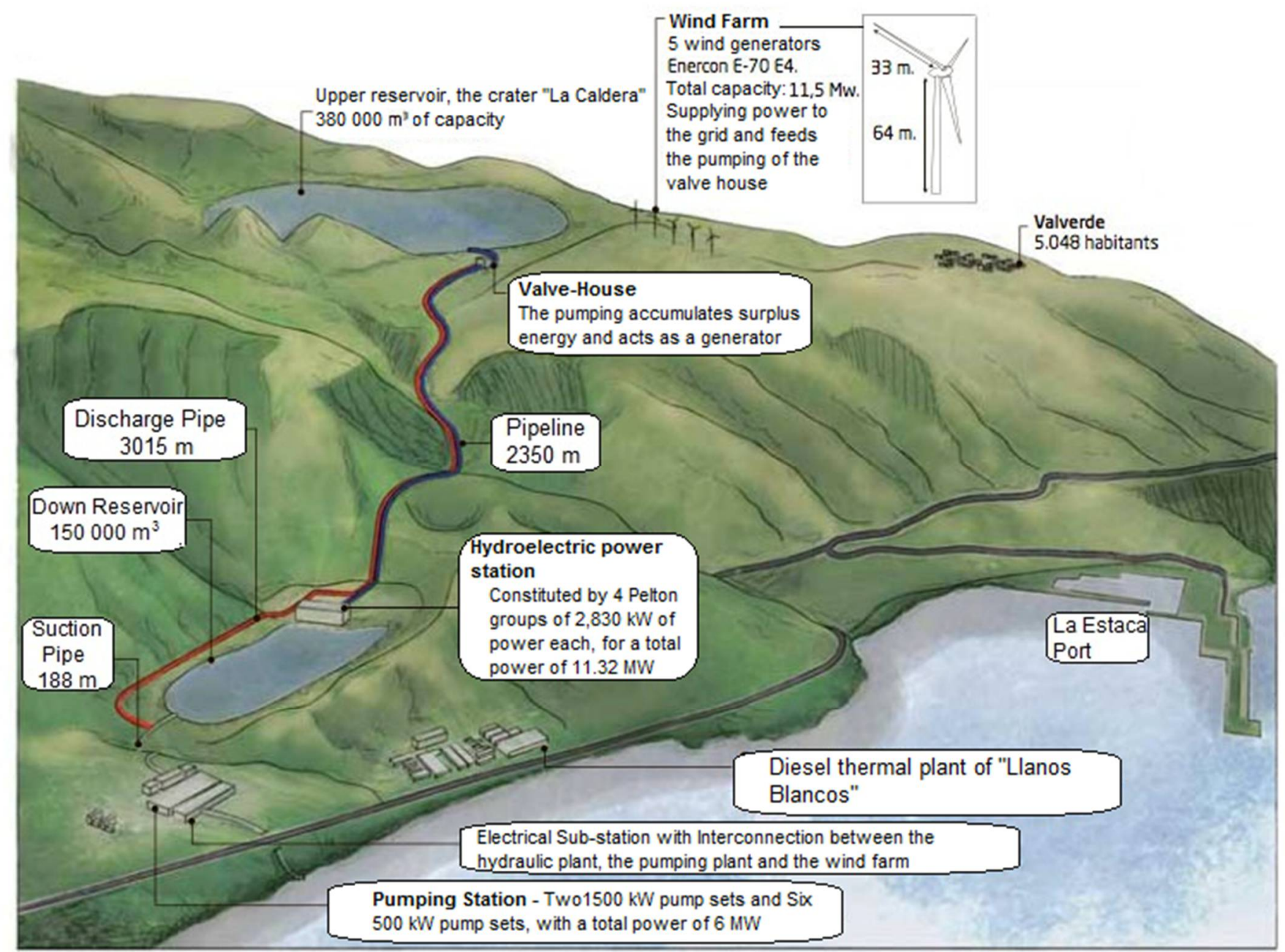

Figure 2 - The basic configuration of the Hydro-wind power plant. 
- The Electrical sub-station that has an interconnection between the hydraulic plant, pumping plant and the wind farm. It is located in an nearby area to the "Llanos Blancos" sub-station with a double bar-system, a double switch and a connection point in the Llanos Blancos Substation.

Thus, storage enables energy savings of fossil fuels and avoids $\mathrm{CO}_{2}$ emissions from the diesel power plant of Llanos Blancos, which currently supplies the electricity demand of the island. Thus, the use of endogenous energy resources (wind and water) reduces the energy dependence and decreases the volatility of oil prices which has an impact on system's exploration. Overall, it reduces the existing extrapeninsular additional cost compensation.

In order to maximize the renewable penetration in the island it is established that the pumping is not performed with electrical energy originated from the thermal power plant but with the energy from the wind farm instead. Therefore, diesel technology will be used to meet the demand only when hydro-wind electricity generation system will be insufficient. This implicates establishing a merit order where wind generation comes first, then the pumped hydroelectric generation (discharge) and finally the conventional generation (diesel). In Table I [4] are shown the main elements of the hybrid hydro-wind electricity generation power plant and it is made a comparison of the performance on the consumption and costs of energy generation with the current production model based exclusively on burning diesel.

Table I - El Hierro energy system comparison: before and after.

\begin{tabular}{|c|c|c|c|c|c|}
\hline \multirow{4}{*}{\multicolumn{2}{|c|}{\begin{tabular}{|l|} 
\\
Conventional generation \\
\end{tabular}}} & \multicolumn{4}{|c|}{$\begin{array}{l}\text { EL HIERRO'S ENERGY } \\
\text { SYSTEM }\end{array}$} \\
\hline & & \multicolumn{2}{|c|}{2011} & \multicolumn{2}{|c|}{2015} \\
\hline & & & & & \\
\hline & & \multicolumn{4}{|c|}{ Diesel power } \\
\hline a) & Nominal output & 13.6 & MW & 15 & MW \\
\hline b) & Annual production & 44.6 & GWh & 13.7 & GWh \\
\hline c) & Annual fuel consumption $(220 \mathrm{~g} / \mathrm{kWh})$ & 9812 & Ton & 3.014 & Ton \\
\hline d) & $\begin{array}{l}\text { Electricity Generation cost } \\
(0.242 \mathrm{kWWh})\end{array}$ & 10.79 & $\mathrm{M} €$ & 3.24 & $\mathrm{M} €$ \\
\hline \multicolumn{6}{|c|}{ Renewable generation } \\
\hline \multicolumn{6}{|c|}{ Wind power } \\
\hline a) & Nominal output & 0 & MW & 11.5 & MW \\
\hline b) & Available annual production & 0 & GWh & 49.6 & GWh \\
\hline c) & Maximum annual production & 0 & GWh & 35.9 & GWh \\
\hline & - Generation at demand period & 0 & GWh & 25 & GWh \\
\hline \multicolumn{2}{|r|}{ Consumed by the pumping station } & 0 & GWh & 9 & GWh \\
\hline \multicolumn{2}{|c|}{ Destined to synchronous compensation } & 0 & GWh & 1.8 & GWh \\
\hline d) & Electricity generation cost & 0 & $€ / \mathrm{kWh}$ & 0.072 & $\epsilon / \mathrm{kWh}$ \\
\hline e) & Total cost & 0 & $\mathrm{ME}$ & 2.58 & $\mathrm{M} €$ \\
\hline \multicolumn{6}{|c|}{ Hydro power capacity } \\
\hline a) & Nominal output & 0 & MW & 10 & MW \\
\hline b) & Annual production & 0 & GWh & 6.4 & GWh \\
\hline c) & Turbine efficiency & 0 & $\%$ & 69.4 & $\%$ \\
\hline \multicolumn{2}{|c|}{ Total generation } & 44.6 & GWh & 56 & GWh \\
\hline \multicolumn{2}{|c|}{$\begin{array}{l}\text { Annual energy demand } \\
\text { (including desalination plant) }\end{array}$} & 44.6 & GWh & 45.4 & GWh \\
\hline \multicolumn{2}{|c|}{ Peak demand } & 7.56 & MW & & MW \\
\hline
\end{tabular}

In 2011, the electricity demand of the island was covered primarily with diesel oil and diesel fuel from the power plant located in White Plains Valverde, the capital of the island, near the port of the stake. In Table II it is possible to see the conventional generation units in El Hierro. By analysing it is possible to observe that the annual fuel consumption and the electricity generation cost of diesel drops roughly by one third which is a very significant saving both economically and ecologically.

The environment benefits both from the newly energy production system and from the changed hydrological plan of El Hierro.
Table II - Available conventional generation units in El Hierro.

\begin{tabular}{|c|c|c|c|c|c|}
\hline Central & Technology & $\begin{array}{c}\mathbf{N}^{\mathbf{o}} \\
\text { Groups }\end{array}$ & $\begin{array}{c}\text { Unit power } \\
\mathbf{( k W )}\end{array}$ & $\begin{array}{c}\text { Total } \\
\text { power (kW) }\end{array}$ & $\begin{array}{c}\text { Current } \\
\text { fuel }\end{array}$ \\
\hline $\begin{array}{c}\text { Llanos } \\
\text { Blancos }\end{array}$ & Motor Diesel & 4 & 1460 & 5840 & Diesel Oil \\
\hline $\begin{array}{c}\text { Llanos } \\
\text { Blancos }\end{array}$ & Motor Diesel & 1 & 1280 & 1280 & Diesel Oil \\
\hline $\begin{array}{c}\text { Llanos } \\
\text { Blancos }\end{array}$ & Motor Diesel & 1 & 1100 & 1100 & Diesel Oil \\
\hline $\begin{array}{c}\text { Llanos } \\
\text { Blancos }\end{array}$ & Motor Diesel & 1 & 1020 & 1020 & Diesel Oil \\
\hline $\begin{array}{c}\text { Llanos } \\
\text { Blancos }\end{array}$ & Motor Diesel & 1 & 775 & 775 & Diesel Oil \\
\hline Total & & & & $\mathbf{1 0 0 1 5}$ & \\
\hline
\end{tabular}

This small island is an example that can be copied by other insular systems all over the World. In terms of environmental impacts this project will avoid an annual consumption of 6000 tonnes of diesel, which is equal to 40000 barrels of oil that would have to be imported by boat to the island, thus generating a saving of over 1.8 million euros per year.

As a consequence, as seen in Table III, it will be avoided a yearly emission of 100 tonnes of $\mathrm{SO}_{2}, 400$ tonnes of $\mathrm{NO}_{x}$ and an emission of 18700 tonnes of $\mathrm{CO}_{2}$ - the main cause of the greenhouse effect.

Table III - Avoided emissions due to the proposed hybrid hydro-wind project.

\begin{tabular}{|c|r|}
\hline Avoided emission gasses & \multicolumn{1}{|c|}{ Avoided Quantity } \\
\hline $\mathrm{NO}_{\mathbf{x}}$ & $100000 \mathrm{Kg} / \mathrm{yr}$ \\
\hline $\mathrm{CO}_{2}$ & $18700000 \mathrm{Kg} / \mathrm{yr}$ \\
\hline $\mathrm{SO}_{2}$ & $400000 \mathrm{Kg} / \mathrm{yr}$ \\
\hline
\end{tabular}

\section{Investment Analysis}

The hydro-wind power plant's economic life is 65, however a part of the wind farm equipment and mechanical and electrical systems of turbines and pumps have to be replaced repeatedly after 20, 25 and 30 years, respectively, in order to ensure the continued operation during the useful life of the construction. This data and other as such is shown in Table IV.

Table IV - EL Hierro's project Life Cycle and amortization years.

\begin{tabular}{|c|c|c|c|}
\hline EQUIPMENT & $\begin{array}{c}\text { NOMINAL } \\
\text { CHARACTERISTICS }\end{array}$ & $\begin{array}{c}\text { CYCLE } \\
\text { LIFE } \\
\text { (YEARS) } \\
\end{array}$ & $\begin{array}{c}\text { AMORTIZATION } \\
\text { (YEARS) }\end{array}$ \\
\hline Wind farm & $\begin{array}{l}5 \times 2.3 \mathrm{MW} \text { wind turbine } \\
\text { generators }\end{array}$ & 20 & 20 \\
\hline Hydro plant & $\begin{array}{c}4 \times 2.83 \mathrm{MW} \text { Pelton } \\
\text { turbine-generator groups }\end{array}$ & 65 & 30 \\
\hline Pumping plant & $\begin{array}{l}2 \times 1.5 \mathrm{MW} \text { pump sets }+ \\
6 \times 500 \mathrm{~kW} \text { pump sets }\end{array}$ & 65 & 30 \\
\hline \multicolumn{2}{|c|}{ Upper reservoir } & \multirow{3}{*}{65} & \multirow{3}{*}{30} \\
\hline Storage capacity & $379,634 \mathrm{~m}^{3}$ & & \\
\hline $\begin{array}{l}\begin{array}{c}\text { Maximum water } \\
\text { level }\end{array} \\
\end{array}$ & $12 \mathrm{~m}^{3}$ & & \\
\hline $\begin{array}{c}\text { Location above } \\
\text { sea level } \\
\end{array}$ & $709.5 \mathrm{~m}$ & & \\
\hline \multicolumn{2}{|c|}{ Lower reservoir } & \multirow{4}{*}{65} & \multirow{4}{*}{30} \\
\hline Storage capacity & $150,000 \mathrm{~m}^{3}$ & & \\
\hline $\begin{array}{l}\text { Maximum water } \\
\text { level }\end{array}$ & $15 \mathrm{~m}$ & & \\
\hline $\begin{array}{c}\text { Location above } \\
\text { sea level }\end{array}$ & $56 \mathrm{~m}$ & & \\
\hline \multicolumn{3}{|c|}{ Hydro and Pumping plants civil work } & 65 \\
\hline
\end{tabular}

Therefore, the time horizon of the profitability calculations that is considered is 20 years, which leads to a review of the hydro-wind power plant remuneration after this period of time by considering sequential replacements of the wind farm, of the mechanical pumping equipment, discharge and the rest of the electrical equipment, and by ensuring the recovery of the unamortized portion of investments in the civil work until the end of its economic life. 
It is established that the preliminary analysis of remuneration should ensure the internal rate of return and free cash flow after tax (IRR of the project) of $7 \%$ in the first 20 years by considering this period without replenishment (coinciding with the economic life of the wind generation) and taking into account the residual value of the plant during the same 20 years.

The techniques that are usually used to assess investments are the Internal Rate of Return (IRR) and the Net Present Value (NPV). The discount rate for which the NPV is equal to zero is the IRR. Both methods highlight the significance of the time value of money and are seen as more complete and simpler than other techniques. Based on the IRR it is studied the financial feasibility of the El Hierro's wind energy and hydro storage power system. Other authors have assessed investments of renewable energy production with storage solutions in isolated systems such as islands. An example of such studies is the integration of wind and hydrogen technologies in the power system of the Corvo island, Azores and the Technical-economic analysis of wind-powered pumped hydrostorage systems of the application model to the island of El Hierro [5, 6].

IRR is the rate of return $-r$ that equates the discounted future cash outflows with initial inflow whose mathematical expression is as follows:

$$
\sum_{n=1}^{N} \frac{F_{n}}{(1+r)^{n}}+F_{0}=0
$$

where:

$\mathrm{F}_{0}=$ cash flow at time zero $\left(\mathrm{t}_{0}\right)$,

$\mathrm{F}_{\mathrm{n}}=$ cash flow at year $\mathrm{n}\left(\mathrm{t}_{\mathrm{n}}\right)$,

$r=\mathrm{IRR}$, and

$n=$ number of years

By replacing the known constants with data values from El Hierro's Wind and hydro pump storage power plant project we obtain the following expression:

Where:

$\mathrm{F}_{0}=-82000000 €$

$\mathrm{R}=7 \%=0,07$

$n=20$ years

$$
\sum_{n=1}^{20} \frac{F_{n}}{(1+0,07)^{n}}-82000000=0
$$

The solution is obtained in Table $\mathrm{V}$ where the discount rate for which the NPV is equal to zero is the IRR, therefore it is achieved the average yearly cash flow.

Table V - Average yearly cash flow at a discount rate of NPV $=0$

\begin{tabular}{|c|c|c|c|}
\hline \multicolumn{3}{|c|}{ NPV of the Wind and hydro pump storage power plant system for El Hierro } \\
\hline Year & $\begin{array}{c}\text { Cash flows } \\
\text { (average per year) }\end{array}$ & $\begin{array}{c}\text { Discount } \\
\text { factor }\end{array}$ & $\begin{array}{c}\text { Present } \\
\text { values }\end{array}$ \\
\hline 0 & $-82000000 €$ & 1 & $-82000000 €$ \\
\hline 1 & $7740219,910 €$ & 0,935 & $7233850.384 €$ \\
\hline 2 & $7740219,910 €$ & 0,873 & $6760607.836 €$ \\
\hline 3 & $7740219,910 €$ & 0,816 & $6318325.080 €$ \\
\hline$\ldots$ & $\ldots$ & $\ldots$ & $\ldots$ \\
\hline 18 & $7740219,910 €$ & 0,296 & $2290051.776 €$ \\
\hline 19 & $7740219,910 €$ & 0,276 & $2140235.304 €$ \\
\hline 20 & $7740219,910 €$ & 0,258 & $2000219.911 €$ \\
\hline NPV= IRR & & & 0 \\
\hline
\end{tabular}

\section{Energy balance forecast during hydro- wind power plant's economic life}

The exploration of a power system with these characteristics is unheard of. To estimate the dynamic evolution of consumption (demand) in the space of several decades and in a context that is required to be sustainable with renewable resources creates risks and uncertainties in a project of this magnitude. According to [7] in the first 10 years of the life of the hydro-wind power plant it is expected an increase of the annual consumption by around $2 \%$. Then until the end of the useful life of the installation it decreases to an annual growth of $1 \%$. With wind pumped hydro storage system functioning at full capacity and for forecasting purposes we consider as constant the annual wind power production and a portion of this production is intended to operate the hydro pumping station and the synchronous compensation.

Precise management of reservoirs is crucial to reach maximum efficiency of the operating system which signifies storing the amount of extra produced wind power by pumping. Therefore, bottom line is to optimize wind and diesel energy sources exploration as well as the number of hours of the pump / turbines operation, which, in consequence, will regulate the water level of the reservoirs. Fig. 3 shows the energy balance forecast for El Hierro Island during the project life cycle.

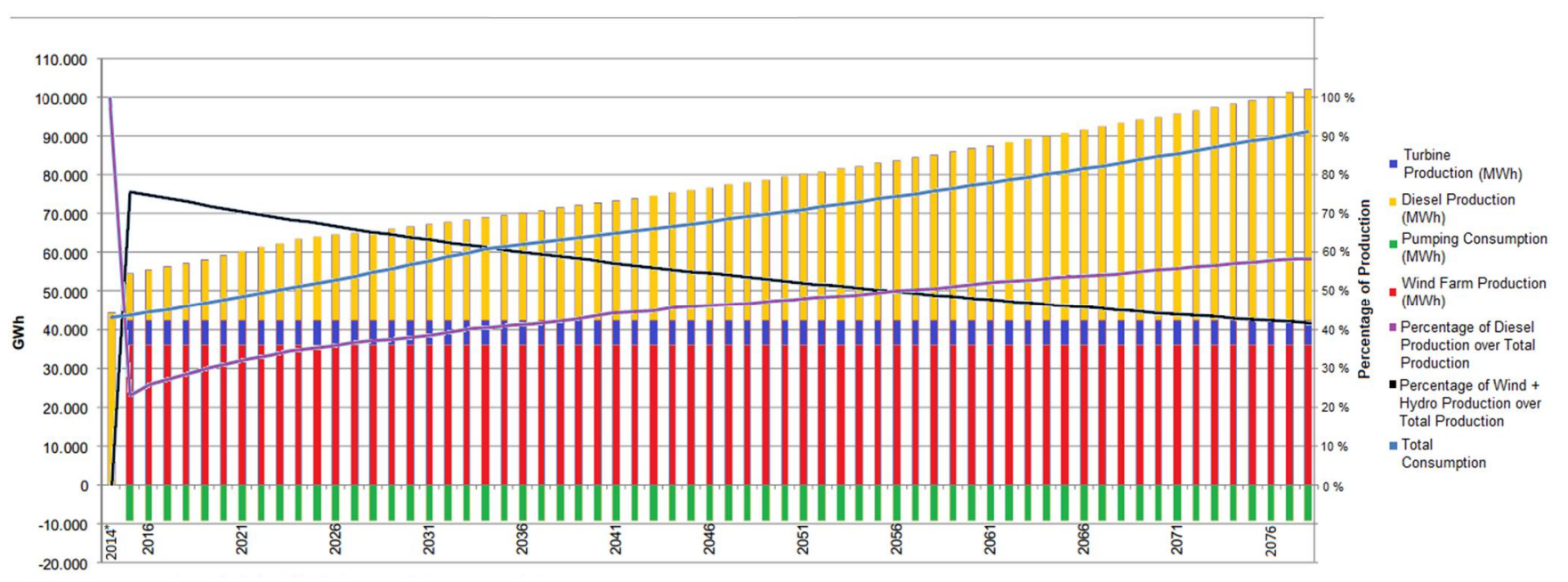

Figure 3- Energy balance forecast for the period 2015-2078. 
Knowing that the pumping energy will never be performed with power from the diesel source and with the aim of maximizing the renewable penetration in the island the diesel resource should solely be used to meet the demand when the hydro pump storage power plant system is insufficient. Following these two rules is expected a strong reduction on diesel generation production in the early years and a gradual increase again in case there are no new additional renewable capacity.

In this way this energetic mix (considering the total demand of the island including the pumping consumption) will vary along the useful life of the hydro pump storage power plant system as follows: the annual wind generation of the study period will vary from the beginning until the end from $66 \%$ - 35\%, respectively, the turbines from $12 \%$ to $6 \%$ (totalizing between $77 \%-41 \%$ of the energy produced from wind farm) and energy from diesel technology between $23 \%-59 \%$ of the total demand. After 20 years, in 2031 wind energy will cover 52\%, 9\% through the hydro discharge and diesel generation will cover $39 \%$ of the total demand of the island. These values reflect the annual mix distribution of each energy source; however there will be periods when it will came near or even exceed these numbers, especially in times of high wind energy production and other periods in which it will decrease.

Therefore, the initial goal of reaching such a renewable penetration to supply the demand by $100 \%$ cannot be achieved relying solely on this project. The maximum penetration of renewable will be reached in 2015 (77\%) then will decrease over the years. This can change since it is expected the incorporation of new renewable generation facilities in the future.

\section{Results after the inauguration}

On 27 June, the Canary Islands leader inaugurated the wind hydro pumped storage power plant that is meant to cover $100 \%$ of the demand for this island using only renewable energy. According to data site Red Eléctrica, on 22 of July the production achieved a first significant output of the five windmills by reaching 3.27 MWh which was spread over 13 hours with a power of 0.2 and $0.3 \mathrm{MW}$ [8]. This is less than $3 \%$ of the daily energy needs of the island so the remaining $97 \%$ continued to come from diesel sources. On 12 August $25 \%$ of the demand was covered by the wind hydro plant during peak hours -6.7 MW [3] as seen in Figure 4.

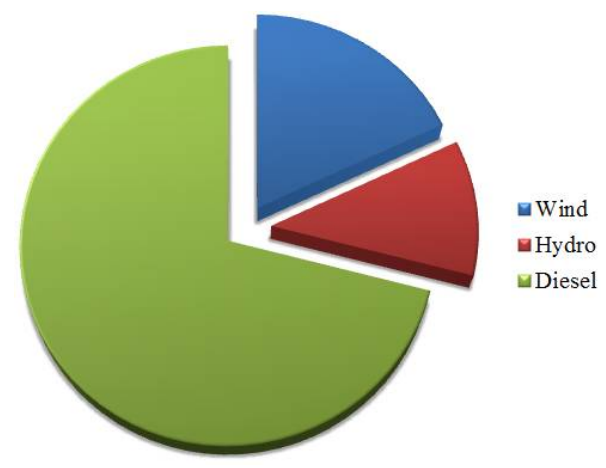

Figure 4 - An instant caption of the production of the wind hydro plant on 12 August.
The tests that are being submitted to the plant are basically setting communications with Red Eléctrica. At Gorona was explained that until the opening of the plant - all the tests that had been made were internal and it had not been provided a single kilowatt to the network, now it has an input to the grid of $10 \%$ at first, then $20 \%, 30 \%$, etc. everything it is being adjusted. The goal for the first year is to make sure that $80 \%$ of the energy provided annually to the grid would be renewable. Gorona recognizes though, that $100 \%$ remains a utopia [9].

The achieved success of the penetration of renewables in the El Hierro island led to establishment of a tendency in the Canaries Islands to become a world laboratory experiences in the field of renewable energy, aiming to reach $30 \%$ renewables penetration in archipelago grid in 2020 [10].

\section{Conclusion}

The isolated energy system in question refers to Spain's EL Hierro, which is so far the world's first islanded sustainable energy system combining hybrid hydroelectric and wind plants to meet its energy needs using wind energy resources. A pumped hydroelectric storage ensures that high electricity demand is always met releasing the stored water through turbines. The hybrid hydro-wind based energy system has an expected life time of 65 years while the wind turbine has a much lower operation life time -20 years. Thus additional investments have to be made to renew wind power plant over the hybrid cycle life period. For the first two decades renewable energy sources contribute with more than $75 \%$ of power needs. However since it is expected an increased pressure on demand due to the growth of the population (estimated on annual grow rate of $2 \%$ ), the incorporation of new renewable generation facilities in the future is expected to maintain or increase the renewable quota.

\section{Acknowledgement}

This work was supported by FEDER funds (European Union) through COMPETE and by Portuguese funds through FCT, under Projects FCOMP-01-0124-FEDER020282 (PTDC/EEA-EEL/118519/2010) and PEst$\mathrm{OE} / \mathrm{EEI} / \mathrm{LA} 0021 / 2013$. Also, the research leading to these results has received funding from the EU Seventh Framework Programme FP7/2007-2013 under grant agreement no. 309048.

\section{References}

[1] G. A. Marrero y F. J. Ramos-Real, «Electricity generation cost in isolated system: The complementarities of natural gas and renewables in the Canary Islands,» Renewable and Sustainable Energy Reviews, vol. 14, n 9, pp. 2808-2818, 2010.

[2] O.-S. Parissis, E. Zoulias, E. Stamatakis, K. Sioulas, L. Alves, R. Martins, A. Tsikalakis, N. Hatziargyriou, G. Caralis y A. Zervos, «Integration of wind and hydrogen technologies in the power system of Corvo island, Azores: A cost-benefit analysis,» International Journal of Hydrogen Energy, vol. 36, nº 13, pp. 8143-8151, 2011. 
[3] «Gorona del Viento El Hierro,» [En línea]. Available: http://www.goronadelviento.es/index.php.

[4] E. Rodrigues, R. Godina, S. Santos, A. Bizuayehu, J. Contreras y J. Catalão, «Energy storage systems supporting increased penetration of renewables in islanded systems,» Energy, vol. 75, pp. 265-280, 2014.

[5] C. Bueno y J. Carta, «Technical-economic analysis of wind-powered pumped hydrostorage systems. Part I: model development,» Solar Energy, vol. 78, $\mathrm{n}^{\circ}$ 3, pp. 382-395, 2005.

[6] C. Bueno y J. Carta, «Technical-economic analysis of wind-powered pumped hydrostorage systems. Part II: model application to the island of El Hierro,» Solar Energy, vol. 78, no 3, p. 396-405, 2005.

[7] Comisión Nacional de Energía, «Propuesta preliminar de retribución de la central hidroeólica de la isla de El Hierro,» 2011.

[8] R. Esteller, «El Hierro, la isla renovable, sólo usa diésel para su suministro eléctrico,» El Economista, [En línea]. Available: http://www.eleconomista.es/.

[9] R. Rodríguez, «La central hidroeólica ya vierte electricidad limpia a la red,» Canarias7, [En línea]. Available: http://www.canarias7.es/.

[10] P. Rivero, «Rivero: El Hierro ahorrará 40.000 barriles de petróleo al año con Gorona del Viento,» El Día.es, [En línea]. Available: http://eldia.es/2014-06-27/canarias/32Rivero-Hierro-ahorrara-barriles-petroleo-ano-GoronaViento.htm. 